\title{
Trace and Heavy Metal Contamination Status of Soil and Water in Artisanal and Small Scale Gold Mining Vicinity in Kuchiko-Hausa, Gurara LGA, Niger State, Nigeria
}

\author{
Sani Aliyu Haruna ${ }^{*}$, Amanabo Musa and Gbodi Timothy Ayinla \\ Department of Biochemistry, Faculty of Natural Sciences, Ibrahim Badamasi Babangida University \\ Lapai, Niger State, Nigeria \\ *Corresponding author's e-mail: elharun14@gmail.com; Phone No.: +2348097995395
}

\begin{abstract}
Mining activities have long been recognized as a major source of environmental contamination associated with heavy metals. In this study, ten (10) trace metals namely $\mathrm{As}, \mathrm{Cd}, \mathrm{Co}, \mathrm{Cr}, \mathrm{Cu}, \mathrm{Fe}, \mathrm{Hg}, \mathrm{Ni}, \mathrm{Pb}$ and $\mathrm{Zn}$ were analysed from water (stream, river and borehole) and soil (surface and sub-soil) samples collected from around the artisanal and small scale gold mining site within the vicinity in Kuchiko-Hausa, Gurara LGA, Niger State, Nigeria using Atomic Absorption Spectroscopy. The result from the water and soil samples showed the while all the investigated trace metals were absent from all the water samples, $\mathrm{Hg}$ was only found with concentration of 0.006 and $0.0053 \mathrm{mg} / \mathrm{mL}$ for the stream and river water samples, the soil samples showed the presence of all the trace metals except $\mathrm{Cd}$ and $\mathrm{Co}$ with As and $\mathrm{Cr}$ found only in the surface soil. All detected trace metals in the samples were all lower than the WHO permissible limits. Periodic and systematic study of the investigated and other metals concentrations is therefore recommended since long-term exposure of these metals poses significant health risk for human, animals and plants.
\end{abstract}

\section{Introduction}

Mining operations, which involve the extraction of minerals and ores beneath and at the surface of the earth, are considered to be accompanied by environmental degradation as well as environmental pollution and associated diseases as a result of some trace

Received: November 4, 2020; Accepted: December 21, 2020

Keywords and phrases: heavy metals, mining, staple, soil, water.

Copyright (C) 2021 Sani Aliyu Haruna et al. This is an open access article distributed under the Creative Commons Attribution License, which permits unrestricted use, distribution, and reproduction in any medium, provided the original work is properly cited. 
elements dispersed into the surrounding environment [1-7]. Mining adversely affects the environment by inducing loss of biodiversity, soil erosion and contamination of diverse class of food, surface water, groundwater and soil and is capable of leading to sink holes because mine wastes generate acid mine drainage (AMD) which contains high amount of sulfide bearing components for example sulfide ores composed of heavy metal components especially lead, mercury, copper, manganese, zinc, nickel, cobalt, arsenic, selenium, molybdenum, chromium, silver and vanadium [8-15]. Contamination of environments caused by heavy metal due to mining activities has become a global issue because of the potential health risks it poses to the local communities where the activities take place [16]. Although some of these trace elements are essential nutrients (cobalt and zinc) or relatively harmless such as silver. However, others like cadmium, mercury and lead are highly poisonous if found at elevated concentrations [17-20]. The variation in the concentrations of these trace elements could be attributed to the differential discharge of untreated effluents originating from small scale and industrial mining, increasing agriculture, and aquaculture sources [21-24].

As a result of the role heavy metals play within the framework of environmental pollution investigation, determining the trace elements distribution patterns and their levels of contamination in soils and water sources of the study area in order to identify the distribution pattern of the elements that are present and the level of the contamination in the mining site is the basic objectives of this study. This study will provide valuable information on the levels and associated health risk of these trace metals in the area, data if utilized will constitute a vital planning tool to health safety regulatory agencies.

\section{Materials and Methods}

\subsection{Study area description}

The study area, Kuchiko-Hausa (Figure 1) is a community situated in Gurara Local Government Area of Niger State, Nigeria. It is on a geographical coordinate of longitude $7^{\circ} 10^{\prime} \mathrm{E}$ and latitude $9^{\circ} 16^{\prime} \mathrm{N}$. The community spread into various neighbouring villages with a large ratio of the inhabitants engaging in local farming and small-scale mining. Farming activities is carried out mostly during the rainy season, with a few on irrigated lands with crops cultivated mostly sorghum, millet, soybeans, cowpeas and maize. The temperature is highest with value $28.7^{\circ} \mathrm{C}$ on average in April and with a lowest average value of $23.9^{\circ} \mathrm{C}$ around August annually. The study area witnessed $1341 \mathrm{~mm}$ of precipitation falls annually. 

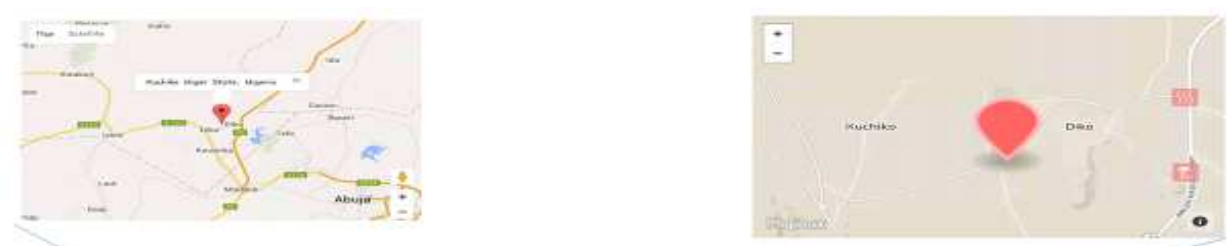

Figure 1. Map of Nigeria showing the position of Niger State and the study area (Kucchiko-Hausa in Gurara Local Government Area (Land and Survey 2012).

\subsection{Samples Collection}

\section{(A) Water samples}

A total of fifteen (15) samples comprising five samples each from river (surface water), stream (surface water) and boreholes (underground water) collected from Kuchiko-Hausa and its environs. They were collected into stoppered-plastic bottles thoroughly washed and rinsed with deionized water Filtration of the water samples was done in the field using $0.45 \mu \mathrm{m}$ diameter disposable filters to ensure the removal of suspended solids before been stored in a stoppered-plastic bottles thoroughly washed and rinsed with deionized water. $5 \mathrm{~mL}$ concentrated nitric acid per litre was added to the samples collected using new syringes at the time of collection, to minimize adsorption of metals onto the container walls [25].The samples were all stored in the refrigerator throughout the period prior to analysis.

\section{(B) Soil samples}

Random sampling method was used to collect soil samples from different points around the Kuchiko-Hausa mining site and at a distance of not more than $1 \mathrm{~km}$ apart. Dutch soil auger to collect twenty (20) core samples each of surface and sub-surface (20$30 \mathrm{~cm}$ depth below the soil surface) [26]. Samples were collected in a clean-labeled polythene bags to avoid contamination. 


\subsection{Chemicals}

All reagents used were of analytical grade and from which standard solutions were prepared. Glassware were thoroughly washed with detergent and rinsed with distilled water.

\subsection{Digestion procedure}

The procedure outlined by Akubue, [27] with slight modifications was adopted for the extraction of trace metals in this soil sample. One gram (1.0 g) each of air and ovendried soil sample previously sieved through a $2 \mathrm{~mm}$ mesh size was weighed and quantitatively transferred into a $25 \mathrm{~mL}$ volumetric flask containing $5 \mathrm{~mL}$ perchloric and concentrated nitric acid mixture in a ratio of 1:2. The vessel was gently swirled and kept in a fume cupboard overnight. The samples were subsequently digested at a temperature of $150^{\circ} \mathrm{C}$ on a hot plate for 3 hours or until frothing ceased. The solution was allowed to cool and filtered through Whatman No. 40 filter paper before been made up to the $25 \mathrm{~cm}^{3}$ mark with distilled water. All samples types (water and soil) were then analyzed using Shimadzu AA 500 Atomic Absorption Spectrophotometer (WINPRO AAS 500 VGP. Spectrum, USA), attached to graphite atomizer with specific hollow cathode lamps for various elements and a printer.

\subsection{Laboratory analysis}

Portions of homogenized soil and water samples digested were quantified for the trace metals; $\mathrm{As}, \mathrm{Cd}, \mathrm{Co}, \mathrm{Cr}, \mathrm{Cu}, \mathrm{Fe}, \mathrm{Hg}, \mathrm{Ni}, \mathrm{Pb}$ and $\mathrm{Zn}$, adopting various analytical techniques and instrumentation in the evaluation of each trace metal, since each element has its peculiar matrix and detection levels.

\subsection{Metal analysis}

The metal analysis was determined by comparing the absorbance $\mathrm{I}_{\mathrm{o}}$ when no analyte exist and $\mathrm{I}_{\text {trans }}$ when analytes are present. Procedural blanks were prepared and aspirated along with the analytical samples in order to correct for background absorption. The limit of detection for the metal was $0.001 \mathrm{ppm}$ while that of the blank was $0.00 \mathrm{ppm}$. The instrumental description for each analyzed metal is presented in Table 1. 
Table 1. Instrumental description of the AAS.

\begin{tabular}{|c|c|c|c|c|}
\hline $\mathrm{S} / \mathrm{N}$ & Metals & Lamp description & $\begin{array}{l}\text { Slit width } \\
\quad(\mathrm{mm})\end{array}$ & Wavelength (nm) \\
\hline 1 & Lead & $\begin{array}{c}\text { Lead hollow cathode lamps } \\
\text { operated at } 10 \mathrm{~m} \AA\end{array}$ & 0.7 & 253.7 \\
\hline 2 & Cadmium & $\begin{array}{l}\text { Cadmium hollow cathode } \\
\text { lamp operated at } 4 \mathrm{~m} \AA\end{array}$ & 0.7 & 228.8 \\
\hline 3 & Arsenic & $\begin{array}{l}\text { Arsenic ultra-lamp operated at } \\
\qquad 10 \mathrm{m \AA}\end{array}$ & 1.0 & 189.0 \\
\hline 4 & Copper & $\begin{array}{c}\text { Multi-element hollow cathode } \\
\text { operated at } 15 \mathrm{~m} \AA\end{array}$ & 1.0 & 324.7 \\
\hline 5 & Cobalt & $\begin{array}{l}\text { Cadmium hollow cathode } \\
\text { lamp operated at } 10 \mathrm{~m} \AA\end{array}$ & 0.7 & 189.0 \\
\hline 6 & Mercury & $\begin{array}{c}\text { Mercury hollow cathode lamp } \\
\text { operated at } 10 \mathrm{m \AA}\end{array}$ & 0.7 & 253.7 \\
\hline 7 & Zinc & $\begin{array}{l}\text { Multi-element hollow cathode } \\
\text { lamp operated at } 12 \mathrm{~m} \AA\end{array}$ & 3.0 & 213.8 \\
\hline 8 & Iron & $\begin{array}{l}\text { Multi-element hollow cathode } \\
\text { lamp operated at } 12 \mathrm{m \AA}\end{array}$ & 0.2 & 248.3 \\
\hline 9 & Nickel & $\begin{array}{l}\text { Multi-element hollow cathode } \\
\text { lamp operated at } 7 \mathrm{~m} \AA\end{array}$ & 0.15 & 232.1 \\
\hline 10 & Chromium & $\begin{array}{c}\text { Chromium hollow cathode } \\
\text { lamp of current } 10 \mathrm{~m} \AA\end{array}$ & 1.0 & 540.0 \\
\hline
\end{tabular}

\subsection{Statistical analysis}

Precision, accuracy and sensitivity of the analytical techniques employed in this research were assured by quadruplet samples, blanks and the method of standard addition. Results were expressed as the mean \pm standard deviation. 


\section{Results}

The results of the trace metal concentrations obtained from the assessment of the quality of the different water sources and soil samples from the study location in comparison with the permissible limits of conventional standard(s) is presented in Tables 2 and 3.

Table 2. Ranges and Mean Concentration Values for Selected Trace Elements in the Various Water Sources around the Study Site.

\begin{tabular}{|c|c|c|c|c|c|}
\hline \multirow{2}{*}{$\begin{array}{c}\text { Trace } \\
\text { Element }\end{array}$} & \multirow{2}{*}{$\begin{array}{l}\text { Concentration } \\
\text { Range (mg/mL) }\end{array}$} & \multirow{2}{*}{$\begin{array}{c}\text { Mean } \pm \text { SD for } \\
\text { QA }\end{array}$} & \multicolumn{3}{|c|}{ Standards $(\mathrm{mg} / \mathrm{mL})$} \\
\hline & & & WHO & EU & NIS \\
\hline Cadmium & $\begin{array}{l}\text { (a)ND } \\
\text { (b)ND } \\
\text { (c) ND }\end{array}$ & - & $0.003^{*}$ & $0.005^{*}$ & $0.003 *$ \\
\hline Arsenic & $\begin{array}{l}\text { (a)ND } \\
\text { (b)ND } \\
\text { (c)ND }\end{array}$ & - & $0.01 * *$ & $0.01 * *$ & $0.01 * *$ \\
\hline Cobalt & $\begin{array}{l}\text { (a)ND } \\
\text { (b)ND } \\
\text { (c)ND }\end{array}$ & - & N/A & N/A & N/A \\
\hline Mercury & $\begin{array}{l}\text { (a) } 0.005-0.012 \\
\text { (b) } 0.001-0.012 \\
\text { (c)ND }\end{array}$ & $\begin{array}{c}0.006 \pm 0.0048 \\
0.0053 \pm 0.0043 \\
-\end{array}$ & $0.006 * *$ & $0.001 * *$ & $0.001 * *$ \\
\hline Nickel & $\begin{array}{l}\text { (a)ND } \\
\text { (b)ND } \\
\text { (c) ND }\end{array}$ & - & $0.02 *$ & $0.02 *$ & $0.02 *$ \\
\hline Chromium & $\begin{array}{l}\text { (a) ND } \\
\text { (b)ND } \\
\text { (c) ND }\end{array}$ & - & $0.05 * *$ & $0.05 * *$ & $0.05^{* *}$ \\
\hline
\end{tabular}

Key: (a) Stream; (b) River; (c) Borehole; ND = Not detected. Note: Lead, Iron, Zinc and Copper were not assessed for; QA = Quintuplet analysis; *Ogbuneke and Ezeibeanu, [28]; ** WHO/FAO [29].

The geochemical result of the concentration of selected trace elements in the surface and sub-surface soils around the Kucchiko-Hausa gold mining site are presented in Table 3. 
Table 3. Ranges and Mean Concentration Values for Selected Trace Elements in the Soil Samples around the Study Site.

\begin{tabular}{|c|c|c|c|}
\hline Trace Element & $\begin{array}{l}\text { Concentration Range } \\
\qquad(\mathrm{mg} / \mathrm{kg})\end{array}$ & Mean \pm SD for QA & $\begin{array}{l}\text { Standards } \\
(\mathrm{mg} / \mathrm{kg})\end{array}$ \\
\hline Copper & $\begin{array}{l}\text { (a) } 0-7.40 \\
\text { (b) } 0-7.40\end{array}$ & $\begin{array}{l}\text { (a) } 7.4 \pm 0.00 \\
\text { (b) } 7.4 \pm 0.00\end{array}$ & $36^{*}$ \\
\hline Lead & $\begin{array}{l}\text { (a) } 0-32.80 \\
\text { (b) } 0-32.80\end{array}$ & $\begin{array}{l}\text { (a) } 32.80 \pm 0.00 \\
\text { (b) } 32.80 \pm 0.00\end{array}$ & $85^{*}$ \\
\hline Zinc & $\begin{array}{l}\text { (a) } 72.18-91.45 \\
\text { (b) } 22.00-83.75\end{array}$ & $\begin{array}{l}\text { (a) } 72.23 \pm 19.62 \\
\text { (b) } 51.34 \pm 20.90\end{array}$ & $50 *$ \\
\hline Iron & $\begin{array}{l}\text { (a) } 4115.85-4251.19 \\
\text { (b) } 1160.10-4253.75\end{array}$ & $\begin{array}{l}\text { (a) } 4269.1 \pm 363.84 \\
\text { (b) } 4035 \pm 1119.77\end{array}$ & $400 * * * *$ \\
\hline Cadmium & $\begin{array}{l}\text { (a) ND } \\
\text { (b) ND }\end{array}$ & $\begin{array}{l}\text { (a) - } \\
\text { (b) - }\end{array}$ & $0.80^{*}$ \\
\hline Arsenic & $\begin{array}{l}\text { (a) } 0-1000 \\
\text { (b) ND }\end{array}$ & $\begin{array}{l}\text { (a) } 307 \pm 0.012 \\
\text { (b) - }\end{array}$ & $50 * *$ \\
\hline Cobalt & $\begin{array}{l}\text { (a) ND } \\
\text { (b) ND }\end{array}$ & $\begin{array}{l}\text { (a) - } \\
\text { (b) - }\end{array}$ & $100 * *$ \\
\hline Mercury & $\begin{array}{l}\text { (a) } 0-25 \\
\text { (b) } 0-0.15\end{array}$ & $\begin{array}{l}\text { (a) } 0.068 \pm 0.0571 \\
\text { (b) } 0.034 \pm 0.0506\end{array}$ & $270 * * *$ \\
\hline Nickel & $\begin{array}{l}\text { (a) } 0.05-1.00 \\
\text { (b) } 0.2-1.00\end{array}$ & $\begin{array}{l}\text { (a) } 0.4 \pm 0.43 \\
\text { (b) } 0.24 \pm 0.30\end{array}$ & $35^{*}$ \\
\hline Chromium & $\begin{array}{l}\text { (a) } 0-700 \\
\text { (b) ND }\end{array}$ & $\begin{array}{l}\text { (a) } 217 \pm 17.81 \\
\text { (b) - }\end{array}$ & $100 *$ \\
\hline
\end{tabular}

Key: (a) Surface soil; (b) Sub-surface soil; ND = Not Detected; QA = Quintuplet analysis; $*$ = WHO [32]; ** = Adagunodo et al., [33]; *** = Raymond and Felix, [34]; $* * * *=$ USEPA [35]. 


\section{Discussion}

Water is one of the most vital natural resources necessary for the existence of life. It covers about $70 \%$ of the earth crust; hence, it is the most abundant substance on the earth surface [28]. Surface water is water in a liquid form, which always flows downwards usually, on mountain slopes, Groundwater has long served as a source of drinking water and it is still very important today. Globally, groundwater is estimated to provide about $50 \%$ of current drinking water supplies. Although most ground waters are still of high quality, at some locations, it is becoming increasingly difficult to maintain the purity of groundwater [30]. The result of the trace elements analysis of stream, river and borehole water from and around the study site showed the absence of all the investigated metals except mercury which was found in concentration range of 0.006 and $0.0053 \mathrm{mg} / \mathrm{mL}$ for the stream and river water sample. $\mathrm{Hg}$ was however not detected in its borehole water. This concentration of $\mathrm{Hg}$ obtained for stream water sample was the permissible limit as stipulated by WHO/FAO but higher than the EU and NIS. The concentration obtained for the river water sample was lower than the permissible limit set by WHO but higher than that set by EU and NIS. The high levels of Hg were not unexpected because of the cruderudimentary and mercury amalgamation techniques adopted in the mining and processing of lead-rich gold ore at Kuchiko-Hausa mining site. The finding from this study is particularly worrisome since exposure to elevated levels of metallic, inorganic and organic mercury can damage the kidney, brain and developing fetus since organic mercury is lipophilic in nature and thus can easily penetrate cell membranes. Mercury exposure also affects the nervous system, as well as alter brain functions thus leading to tremors, shyness, irritability, memory problems and changes in hearing or vision. Shortterm exposure to metallic mercury vapors at higher levels can lead to vomiting, nausea, skin rashes, diarrhea, lung damage, high blood pressure, etc., while short-term exposure to organic mercury poisoning can lead to depression, tremors, headache, fatigue, memory problems, hair loss, etc. Chronic levels of mercury exposure can lead to "erethism", a disease condition characterized by excitability, tremor of the hands, memory loss, timidity, and insomnia [31].

The results showed that $\mathrm{Cu}, \mathrm{Pb}, \mathrm{Zn} \mathrm{Fe}, \mathrm{Hg}$ and $\mathrm{Ni}$ were found to be present in both the surface and sub-soil around the investigated mine site. While $\mathrm{Cr}$ and As were found only in the surface soils, $\mathrm{Cd}$ and $\mathrm{Co}$ were not reported in the investigated soils. The mean concentrations of $\mathrm{Cr}(217 \mathrm{mg} / \mathrm{kg})$ observed in the surface soil exceeded the Clarke value of $83 \mathrm{mg} / \mathrm{kg}$ in the soil samples around the Kucchiko-Hausa mining mines. The mean 
values of $\mathrm{Fe}(4269.1$ and $4035 \mathrm{mg} / \mathrm{kg})$ in the surface and sub-surface soils respectively also exceeds the Clarke's value 35,000 mg/kg. Mean values of $\mathrm{Cu}(7.4 \mathrm{mg} / \mathrm{kg})$ was lower than the Clarke's values of $25 \mathrm{mg} / \mathrm{kg}$ obtained in the soil samples close to the Enyigba mines. While the surface and sub-soil have the same $\mathrm{Cu}$ and $\mathrm{Pb}$ mean concentrations, the concentration of $\mathrm{Zn}, \mathrm{Fe}, \mathrm{Hg}$ and $\mathrm{Ni}$ were observed to be higher in the surface soil than in the sub soil. These metals under acute exposure, lead to loss of appetite, fatigue, sleeplessness, hallucinations, vertigo, renal dysfunction, hypertension and arthritis among others while chronic exposure can result in birth defects, mental retardation, autism, psychosis, allergies, paralysis, weight loss, dyslexia, hyperactivity, muscular weakness, kidney damage, brain damage, coma and may even cause death [31, 36-40].

\section{Conclusion}

The concentration levels of all investigated parameters from both sample types were mostly within the World Health Organization (WHO) permissible levels. This could probably be due to the fact the mining operations in the site are low scale and artisanal in operation unlike other sites where mechanized mining techniques could predispose release of more pollutants and tailings.

\section{References}

[1] D.C. Adriano, Bioavailability of trace metals, in: Trace Elements in Terrestrial Environments, Springer, New York, 2001, pp. 61-89. https://doi.org/10.1007/978-0-387-21510-5_3

[2] P. Higueras, R. Oyarzun, J. Oyarzun, H. Maturana, J. Lillo and D. Morata, Environmental assessment of copper-gold-mercury miningin the Andacollo and Punitaqui districts, Northern Chile, Appl. Geochem. 19 (2004), 1855-1864.

https://doi.org/10.1016/j.apgeochem.2004.04.001

[3] S. Oelofse, Mine water pollution-acid mine decant, effluent and treatment: a consideration of key emerging issues that may impact the State of the Environment, in: Mining: Environment and Health Concerns, The Icfai University Press, 2008, pp. 83-91.

[4] R. Lacatusu, G. Citu, J. Aston, M. Lungu and A.R. Lacatusu, Heavy metals soil pollution state in relation to potential future mining activities in the Rosia Montana area, Carpathian J. Earth Environ. Sci. 4 (2009), 39-50.

[5] K. Kodom, J. Wiafe-Akenten and D. Boamah, Soil heavy metalpollution along Subinriver in Kumasi, Ghana; using X-ray fluorescence (XRF) analysis, in: Conference Information: 20th International Congress on X-ray Optics and Microanalysis, X-ray 
Optics and Microanalysis, Proceedings Book Series, Vol. 1221, AIP Conference Proceedings, 2010, pp. 101-108. https://doi.org/10.1063/1.3399235

[6] P.K. Sahoo, S. Tripathy, M.K. Panigrahi and S.M. Equeenuddin, Geochemical characterization of coal and waste rock from a highsulfur coalfield, India: implication for acid and metal generation, J. Geochem. Explor. 145 (2014), 135-147.

https://doi.org/10.1016/j.gexplo.2014.05.024

[7] A. Potra, J.W. Dodd and L.S. Ruhl, Distribution of trace elements and Pb isotopes in stream sediments of the tri-state mining district (Oklahoma, Kansas, and Missouri), USA, Appl. Geochem. 82 (2017), 25-37. https://doi.org/10.1016/j.apgeochem.2017.05.005

[8] R. Hakkou, M. Benzaazoua and B. Bussiere, Acid mine drainage at the abandoned Kettara Mine (Morocco): 1. Environmental characterization, Mine Water Environ. 27 (2008), 145-159. https://doi.org/10.1007/s10230-008-0036-6

[9] A. Khalil, L. Hanich, A. Bannari, L. Zouhri, O. Pourret and R. Hakkou, Assessment of soil contamination around an abandoned mine in asemi-arid environment using geochemistry and geostatistics: preworkof geochemical process modeling with numerical models, J. Geochem. Explor. 125 (2013), 117-129.

https://doi.org/10.1016/j.gexplo.2012.11.018

[10] S.C. Obiora, A. Chukwu, S.F. Toteu and T.C. Davies. Contamination ofthe potable water supply sources in the lead-zinc mining communitiesof Enyigba, Southeastern Nigeria, Mine Water Environ. 2 (2018), 234-240. https://doi.org/10.1007/s1023 0-018-0550-0

[11] J. Moye, T. Picard-Lesteven, L. Zouhri, K. El Amari, M. Hibti and A. Benkaddour. Groundwater assessment and environmentalimpact in the abandoned mine of Kettara (Morocco), Environ. Pollut. 231(Pt 1) (2017), 899-907.

https://doi.org/10.1016/j.envpol.2017.07.044

[12] P.N. Obasi and B.E.B.Akudinobi. Geochemical assessment of heavymetal distribution and pollution status in soil/stream sedimentin the Ameka mining area of Ebonyi state, Nigeria, Afr. J. Geosci. Res. 3(4) (2015), 01-07.

[13] K. ElAmari, P. Valera, M. Hibti, S. Pretti, A. Marcello and S. Essarraj. Impact of mine tailings on surrounding soils andground water: case of Kettaraold mine, Morocco. J Afr Earth Sci. 100 (2014), 437-449. https://doi.org/10.1016/j.jafrearsci.2014.07.017

[14] B.E. Davies, C. Bowman, T.C. Davies and O. Selinus, Medical Geology: Perspectives and Prospects, Essentials of Medical Geology, Springer, Dordrecht, 2013, pp. 1-13. https://doi.org/10.1007/978-94-007-4375-5_1

[15] H.L. Hartman, (1992) SME mining engineering handbook, Society forMining, Metallurgy, and Exploration Inc, Littleton, 1992, p3. 
[16] S.C. Obiora, A. Chukwu, S.F. Toteu and T.C. Davies. Assessment of heavy metal contamination in soils around $\mathrm{Pb}-\mathrm{Zn}$ mining areas in Enyigba, Southeastern Nigeria, $J$. Geol. Soc. India 87 (2016), 453-462. https://doi.org/10.1007/s12594-016-0413-x

[17] I.N. Aigbedion, Environmental pollution in the Niger-delta, Nigeria, Inter. Discipl. J. Enugu. Niger. 3(4) (2005), 205-210.

[18] M.A. Sheikh, N.M. Noah, K. Tsuha and T. Oomori, Occurrence of tributyltin compounds and characteristics of heavy metals, Int. J. Environ. Sci. Technol. 4(1) (2007), 49-60. https://doi.org/10.1007/BF03325961

[19] C.M. Zvinowanda, J.O. Okonkwo, P.N. Shabalala and N.M. Agyei, A novel adsorbent for heavy metal remediation in aqueous environments, Int. J. Environ. Sci. Technol. 6(3) (2009), 425-434. https://doi.org/10.1007/BF03326081

[20] M.M.S. Nakayama, Y. Ikenaka, K. Muzandu, K. Choongo, B. Oroszlany, H. Teraoka, N. Mizuno and M. Ishizuka, Heavy metal accumulation in lake sediments, fish (Oreochromis niloticus and Serranochromis thumbergi), and crayfish (Cherax quadricarinatus) in Lake Itezhi-tezhi and Lake Kariba, Zambia, Arch. Environ. Contam. Toxicol. 59(2) (2010), 291-300. https://doi.org/10.1007/s00244-010-9483-8

[21] M.V. Chatterjee, E.V. Silva Filho, S.K. Sarkar, S.M. Sella, A. Bhattacharya, K.K. Satpathy and B.D. Bhattacharya, Distribution and possible source of trace elements in the sediment cores of a tropical macrotidal estuary and their ecotoxicological significance, Environ. Int. 33(3) (2007), 346-356. https://doi.org/10.1016/j.envint.2006.11.013

[22] A. Binelli, S.K. Sarkar, M. Chatterjee, C. Riva, M. Parolini, B. Bhattacharya and K.K. Satpathy, A comparison of sedimentquality guidelines for toxicity assessment in the Sunderbanwetlands (Bay of Bengal, India), Chemosphere 73(7) (2008), 1129-1137. https://doi.org/10.1016/j.chemosphere.2008.07.019

[23] M.S. Achary, S. Panigrahi, K.K. Satpathy, R.K. Prabhu and R.C. Panigrahy. Health risk assessment and seasonal distribution ofdissolved trace metals in surface water of Kalpakkam, south westcoast of Bay of Bengal, Int. J. Reg. Stud. Mar. Sci. 6 (2006), 96108. https://doi.org/10.1016/j.rsma.2016.03.017

[24] M.S. Achary, K.K. Sapathy, S. Panigrahi, A.K. Mohanty, R.K. Padhi, S. Biswas, R.K. Prabhu, S. Vijayalakshmi and R.C. Panigrahy. Concentration of heavy metals in the food chain components ofthe nearshore coastal waters of Kalpakkam, south east coast of India, Int. J. Food Control 72 (2017), 232-243. https://doi.org/10.1016/j.foodcont.2016.04.028

[25] A. Alpha, Standard methods for examination of water and wastewater, American Public Health Assoc. 16th edition, Washington D.C., 1995, pp. 23-29.

[26] E.N. Onyeika, S.I. Ogbuja and N.M. Nwinuka. Inorganic ion levels of soils and streams 
in some areas of Ogoni land, Nigeria as affected by crude oil spillage, Environ. Monitoring Assess 77 (2002), 151-205.

[27] P.I. Akubue, Poison in our environment and drug over-dosage. In: A guide for health professionals and the lay public. (1st ed.), Nigeria Rex Charles and Patric Ltd, 1997, p6077.

[28] O.C. Chikaa and E.A. Prince. Comparative assessment of trace and heavy metals in available drinking water from different sources in the centre of Lagos and off town (Ikorodu LGA) of Lagos State, Nigeria, Advanced Journal of Chemistry 3(1) (2020), 94104. https://doi.org/10.33945/SAMI/AJCA.2020.1.9

[29] FAO/WHO, Codex Alimentarius Commission, Food additives and contaminants. Joint FAO/WHO food standards programme, ALINORM 01/12A, 2001, p1-289.

[30] O.G. Adewuyi, O.U. Oputu and M.A. Opasina, J. Water Res. Protect. 2 (2010), 849-853.

[31] P.N. Obasi and B.B. Akudinobi, Potential health risk and levels of heavy metals in water resources of lead-zinc mining communities of Abakaliki, Southeast Nigeria, Applied Water Science 10 (2020), 184. https://doi.org/10.1007/s13201-020-01233-z

[32] WHO/FAO/IAEA, World Health Organisation Switzerland; Genera; Trace Elements in Human Nutrition and Health, Wisconsin, 1996, p. 19-48.

[33] T.A. Adagunodo, L.A. Sunmonu and M.E. Emetere. Heavy metals' data in soils for agricultural activities, Data in Brief 18 (2018), 1847-1855.

https://doi.org/10.1016/j.dib.2018.04.115

[34] R.A.Wuana and F.E. Okieimen, Heavy metals in contaminated soils: A review of sources, chemistry, risks and best available strategies for remediation, International Scholarly Research Network, ISRN Ecology 2011, Article ID 402647, 1-20. https://doi.org/10.5402/2011/402647

[35] United States Environmental Protection Agency (USEPA), Environmental criteria and assessment office, Cincinnati, OH: United States Environmental Protection Agency; Integrated Risk Information System (IRIS), 2001.

[36] I. Lidsky and J.S. Schneider, Lead neurotoxicity in children: basic mechanisms and clinical correlates, Brain 126 (2003), 5-19. https://doi.org/10.1093/brain/awg014

[37] L. Jarup, Hazards of heavy metal contamination, British Medical Bulletin 68 (2003), 167182. https://doi.org/10.1093/bmb/ldg032

[38] J.Y.J. Barbee and T.S. Prince, Acute respiratory distress syndrome in a welder exposed to metal fumes, South Med. J. 92 (1999), 510-520.

https://doi.org/10.1097/00007611-199905000-00012 
[39] C.C. Ogbuneke, B.Sc. Project, Dept. of Science Lab. Tech., Federal University of Technology, Owerri, 2007, pp. 6-38.

[40] Nigeria Industrial Standards (NIS), Nigerian Standards for Drinking Water Quality, 2007, p. 5 . 